ks. Ignacy Bokwa

UKSW Warszawa

DOI: $10.15290 /$ std.2015.01.04

\title{
NIEZBYWALNY I CIĄGLE AKTUALNY WKŁAD KARLA RAHNERA SJ (1904-1984) DO WSPÓŁCZESNEJ ANTROPOLOGII TEOLOGICZNEJ
}

\section{INDESTRUCTIBLE AND ALWAYS CURRENT CONTRIBUTION OF KARL RAHNER SJ (1904- 1984) TO THE CONTEMPORARY THEOLOGICAL ANTHROPOLOGY}

Karl Rahner is undoubtedly one of the greatest theologians of the twentieth century. He has influenced and is still having an impact on its shape and trends. It can be seen from the example of his theological anthropology. His vision of a man is decidedly theological and perceived as such becomes the most important foundation of anthropology. The message of faith constitutes the highest standard and an unregulated significant expression of a man. Theological interpretation of its essence occurs in the historical and living conditions of dependency and inadequacy of a man. A man is a supernatural existential (übernatürliches Existential), so as a being is qualified to grace by nature, to the supernatural, and finally defined by that reality. The most important event in human life is the fact that God turned to him and revealed him. It allows to read all theological dogmas as statements of anthropology. A man is in fact the point of intersection of God's revelation and historical experience of himself. For Rahner a man in his deepest essence is a spirit in the world and a hearer of God's words, a recipient of his revelation possible for recognition by the natural mind. A man is also potentia oboedientialis - an active potency to show God the obedience of faith and love as his supernatural grace. According to Rahner, Christology is the most radical, exceeding everything repetition of theological anthropology. Rahner starts his reflection in the field of theological 
anthropology from a man and his experience, in order to demonstrate that a man does not exist without God, moreover, a man is unthinkable. In the era of postmodern blurring of the essential philosophical and theological concepts this German theologian presents the basic truth about the legitimacy of being a Christian, the beauty of humanity relies on God, and also about the nonsense and tragedy of atheism. The whole theological thought and activity of Karl Rahner served to demonstrate the falsity and harm of theoretical as well as existential dimension of atheism. A man confirms by every act of his being, thinking and wanting that there is a God who loves his creation.

Key words: theological anthropology, Karl Rahner, transcendental theology, relationship of Christology and anthropology, atheism.

30 marca 2014 roku minęło 30 lat od śmierci Karla Rahnera SJ. To wystarczająco wiele czasu, aby zapomnieć nawet o postaci wybitnej. W przypadku tego wielkiego niemieckiego teologa katolickiego byłaby to jednak niepowetowana szkoda. Wywarł on bowiem ogromny wpływ na kształt chrześcijańskiej teologii swoich czasów, ale też na tendencje rozwojowe współczesnej refleksji teologicznej. Niniejsze opracowanie, z konieczności syntetyczne i zwarte, stawia sobie za cel próbę sformułowania odpowiedzi na następujące pytanie: na czym polega istota i aktualność wkładu Karla Rahnera do współczesnej antropologii teologicznej?

\section{Radykalnie teologiczna wizja człowieka}

Nie ulega wątpliwości, że pomimo wyraźnej predylekcji dla języka filozoficznego i skomplikowanych ciągów myślowych, Karl Rahner proponuje teologiczną wizję człowieka: każda inna wizja człowieka uzależniałaby bowiem teologię od konkretnej antropologii ${ }^{1}$. Inna rzecz to pytanie, o jakiej teologii mówi tu Rahner, skoro miałaby ona być wewnętrznie wolna od zależności od jakiejś filozofii? Czy jest do pomyślenia teologia bez filozofii? Paradoksalnie w kontekście jego „teologii/chrystologii oddolnej” brzmi stwierdzenie, że nie jest w tym momencie istotne to, co o sobie człowiek wie - „naturalnie” - a więc niezależnie od historycznego Objawienia Bożego. To bowiem teologia jednoznacznie dyktuje obraz człowieka. Koncepcja teologiczna staje się najważniejszym fundamentem antropologii². Światło wiary jest tu elementem decydującym, „znoszącym” światło naturalnego rozumu i czyniącym go swoim integralnym elementem.

\footnotetext{
1 Por. K. Rahner, Antropologie (Theologische), w: Lexikon für Theologie und Kirche, Bd. I, J. Höfer, K. Rahner (Hg.), 2. Aufl., Freiburg/Br. 1986, kol. 623.

2 Por. K. Góźdź, Teologia człowieka. Z najnowszej antropologii niemieckiej, Lublin 2006, s. 226-256: „Koncepcja teologiczna fundamentem antropologii”.
} 
Przesłanie wiary staje się najwyższą normą istotnej wypowiedzi o człowieku, także wtedy, kiedy zostaje ono poddane aposteriorycznemu i koniecznemu oglądowi tegoż człowieka, dokonywanemu w świetle jego doświadczenia siebie samego. W warunkach historycznej i bytowej zależności oraz niewystarczalności człowieka dokonuje się teologiczna interpretacja jego istoty ${ }^{3}$. Człowiek, jak to Rahner wielokrotnie podkreślał, jest nadprzyrodzonym egzystencjałem (übernatürliches Existential) ${ }^{4}$, a więc bytem $z$ natury powołanym do łaski, do nadprzyrodzoności i przez tę rzeczywistość ostatecznie określonym. Ze swej natury człowiek jest jednak bytem nakierowanym na rzeczywistość doświadczalną, aposterioryczną. To sprawia, że początek wszelkiej refleksji intelektualnej tkwi w historii. W tej historii przychodzi Boże Objawienie, w historii urzeczywistnia się też akt wiary. Karl Rahner podkreśla, że pomiędzy założonym, absolutnym, wypływającym z wiary wyjaśnieniem istoty człowieka a historyczną weryfikacją tego faktu, istnieje wewnętrzna zgodność.

W tej perspektywie należy rozumieć podstawową tezę Rahnerowskiej antropologii teologicznej: „Wyznający chrześcijańską wiarę człowiek pojmuje siebie - mimo i w swojej stworzoności i grzeszności - jako ten, do którego zwrócił się w historii Bóg, i to przy pomocy Słowa absolutnego, wolnego, a więc łaskawego samootwarcia Boga w Jego jak najbardziej własnym życiu" ${ }^{\prime}$.

3 „Dieser gesuchte Ansatz darf als theologischer, der den Gehörthabenden und Glaubenden voraussetzt, durchaus als aposteriorisch erscheinen, das heißt in dem liegen, was in der geschichtlichen Glaubensbotschaft gehört ist als Aussage über den Menschen. Diese Botschaft als die Gottes selbst tritt natürlich von ihrer Herkunft her (trotz ihrer geschichtlichen Aposteriorität) mit dem Anspruch auf, das Umfassende und Normgebende und nicht das Normierte zu sein. Wie das möglich ist trotz der Tatsache, daß das aposteriorisch Gehörte (vor allem wenn es den Menschen selbst betrifft) unter das Maß des apriorischen und notwendigen Selbstverständnisses zu geraten scheint - diese für den Bestand einer echten theologischen Anthropologie entscheidende Frage zu klären ist gerade Aufgabe einer theologischen Anthropologie. Es ist die Frage, warum eine Deutung des Menschen, die in geschichtlicher Kontingenz von außen kommt, um als entscheidende und grundlegende Interpretation des Menschen kommen zu können (was sie doch als theologische sein will und sein muß), nicht immer schon zu spät kommt, wenn anders der Mensch das Wesen eines ursprünglichen Selbstbesitzes, das Befindliche Wesen [...] das man nicht vorfinden kann, eben Subjekt ist" (K. Rahner, Anthropologie (Theologische), kol. 623).

$4 \quad$ Por. H. Verweyen, Wie wird ein Existential übernatürlich? Zu einem Grundproblem der Anthropologie K. Rahners, „Trierer Theologische Zeitschrift” 95(1986) z. 2, s. 115-131.

$5 \quad$ K. Rahner, Anthropologie (Theologische), kol. 624. Znamiennym jest fakt, że hasło: Antropologia - teologiczna, cz. C: Antropologia systematyczna, zamieszczone w Encyklopedii Katolickiej KUL, rozpoczyna się od pytania o genezę człowieka. Oznacza to zgoła inne podejście do tematu. A Rahner zaczynał pisać swoje pierwsze dzieła już przed II wojną światową (por. W. Granat, Antropologia - teologiczna, C: Antropologia systematyczna, w: Encyklopedia Katolicka, t. I, red. F. Gryglewicz, R. Łukaszyk, Z. Sułowski, Lublin 1973, kol. 698-702. 
Otwierającemu się Bogu odpowiada otwarta struktura ludzkiego bytu, jego duchowość ${ }^{6}$.

Ta istotna teza niemieckiego teologa pozwala na urzeczywistnienie jego słynnego postulatu, by wszystkie dogmaty odczytywać jako stwierdzenia teologicznej antropologii. Człowiek jest bowiem punktem przecięcia Bożego Objawienia i historycznego doświadczenia siebie samego. Z praktycznego punktu widzenia Rahner doradza jednak ostrożność: urzeczywistnienie postulatu interpretacji całości dogmatyki przez pryzmat teologicznej antropologii nie może jednak prowadzić do wchłonięcia tej pierwszej przez drugą.

W świetle radykalnej interpretacji istoty ludzkiego bytu staje się możliwe ustalenie głównych dymensji człowieka. Podstawową jest jego stworzoność, pozwalająca rozróżnić między naturą a łaską. Rahner daje pierwszeństwo indywidualnemu bytowi człowiek przed jego wymiarem społecznym. Historyczny konkret ludzkiego istnienia staje się miejscem doświadczenia jego nieskończonej otwartości na Boga - w tym wszystkim, co Bogiem nie jest. Cecha otwartości na Boga ma dwa wymiary - pozytywny i negatywny - i to tak, że poruszając się w obu kierunkach, wartość ta rośnie, w obliczu nieporównywalnego Boga.

Dla Rahnera człowiek w swej najgłębszej istocie jest duchem w świecie ${ }^{7}$ i słuchaczem Bożego słowa ${ }^{8}$, adresatem Jego Objawienia, możliwego do rozpoznania przez naturalny umysł. Boże Objawienie to nie rodzaj intelektualnej informacji, ale coś o wiele więcej - jest to bowiem tak radykalne samootwarcie się Boga, że człowiek nie jest w stanie zareagować na nie inaczej jak tylko w postawie absolutnego, a więc miłującego posłuszeństwa wiary. Dzięki temu aprioryczna zdolność słuchania Bożego Objawienia przychodzącego $z$ historii nie staje się jedynie potwierdzeniem danej, wraz ze stworzonością, zdolności słuchania. Człowiek jest jednak zdolny także do niewiary, do grzesznego zamknięcia się na nieskończoną otwartość Boga w Jego samoudzieleniu się. Owo nie powiedziane Bogu nie niszczy wprawdzie metafizycznej natury człowieka, lecz paradoksalnie potwierdza ogrom i całkowitą darmowość łaskawego objawienia się Boga. Człowiek w żaden sposób nie jest w stanie zaprzeczyć swojej podstawowej tożsamości bytowej,

6 „Człowiek jest więc - według Rahnera-konkretnym bytem, który ma otwartą duchowość. Jest też bytem, który odznacza się wolnością. W tej wolności człowiek stoi wobec wolnego Boga, który może się objawić w historii przez słowo. Jest to najpełniejsza aktualizacja historii. Człowiek jest tym, który jest w swojej historii nasłuchującym Słowa Bożego" (K. Góźdź, Teologia człowieka..., s. 241).

7 Por. K. Rahner, Geist in Welt. Zur Metaphysik der endlichen Erkenntnis bei Thomas von Aquin, Innsbruck 1939.

$8 \quad$ Por. idem, Hörer des Wortes. Zur Grundlegung einer Religionsphilosophie, München 1941. 
jaką jest bycie potentia oboedientialis - aktywną możnością okazania Bogu posłuszeństwa wiary i miłości jako Jego nadprzyrodzonej łasce?.

Ta cecha potencji posłuszeństwa względem Boga staje się dla niemieckiego jezuity punktem wyjścia dla zbudowania teologicznego rozumienia tego wszystkiego, co rozumiemy pod pojęciem ludzkiej duchowości, w której mieszczą się takie przymioty jak transcendencja, wolność, wieczna trwałość w postaci nieśmiertelności ludzkiej osobowości.

Historyczność możności wsłuchiwania się w Boże Objawienie w postaci Wcielonego Słowa pozwala spojrzeć na ludzką historyczność jako na wypowiedź typu teologicznego. Dopiero wtedy z pełnym spokojem można traktować o ludzkim zakorzenieniu w stworzony przez Boga świat, o jego cielesności, o ludzkiej płciowości jako istotnym wymiarze życia społecznego, urzeczywistniającego się w rodzinie, narodzie, państwie i Kościele. Dopiero wtedy, gdy uwzględni się teologiczny punkt wyjścia - i dojścia - człowieka, sensownym staje się mowa o agonalności jego bycia człowiekiem tu i teraz, o historycznym uwarunkowaniu i niemożliwej do pokonania kondycji „wrzucenia w istnienie”.

Człowiek został obdarowany nie tylko stworzonością i stworzeniem, ale samym Bogiem - przypomina wielokrotnie Rahner. Z tej racji teologiczną antropologię mogą tworzyć jedynie te wypowiedzi, które ustawicznie charakteryzują człowieka jak egzystujące w historii stworzenie Boże. Tak można dojść do właściwej nauki o Bogu jako Jedynym i Trójjedynym. Jednakże każda wypowiedź o Bogu będzie zawierała w sobie jaką́s prawdę o człowieku jako o tym, który przez Niego został obdarowany łaską. Człowiek nie może być sobą inaczej jak tylko we właściwości bycia eks-centrycznie nakierowanym na Boga, gdyż dopiero wtedy jest jako człowiek człowiekiem. Żadna wypowiedź o Bogu nie może pomijać egzystencjalnej sytuacji człowieka.

\section{Chrystologiczna konkretyzacja antropologii teologicznej}

Taka teo-logiczna podbudowa antropologicznej refleksji pozwala postawić pytanie o relację chrystologii i teologicznej antropologii ${ }^{10}$. Niebezpieczną iluzją teologii - zdaniem Rahnera - było bezrefleksyjne podejście do znaczenia pojęcia człowieka, gdy przychodziło powiedzieć, że Jezus Chrystus był prawdziwym człowiekiem. Odwołanie jedynie do naszego doświadczenia bycia człowiekiem, pozbawionego koniecznego teologicznego horyzontu i teologicznych pryncypiów, o których była mowa powyżej, prowadziło do

9 Por. K. Góźdź, Teologia człowieka..., s. 251-252: „Samoudzielenie się Boga”.

10 Por. I. Bokwa, Christologie als Anfang und Ende der Anthropologie. Über das gegenseitige Verhältnis zwischen Christologie und Anthropologie bei Karl Rahner, Frankfurt am Main - Bern - New York - Paris 1990. 
niebezpiecznego zawężenia chrystologii. Co najwyżej można było bowiem stwierdzić, czego z naszej ludzkiej kondycji nie znajdziemy u Jezusa Chrystusa, a więc grzeszności. Z tej racji mowa o Jezusie Chrystusie jako człowieku na „idealny sposób”, jako przykładzie dla człowieka i idealnym modelu teologicznej antropologii, trafiała właściwie w pustkę. Teologiczna antropologia może formułować swoje podstawowe twierdzenia o człowieku (np. Zmartwychwstanie, przebóstwiająca łaska Boża) dopiero wtedy, gdy zaistnieje chrystologia. Ta zaś bazuje na przekonaniu, że człowieczeństwo Boskiego Logosu nie jest jedynie bezwiednym instrumentem, przy pomocy którego niewidzialny Bóg staje się zauważalny w świecie, lecz to człowieczeństwo staje się tym, kim jest sam Bóg - pozostając ciągle rzeczywistym, prawdziwym człowieczeństwem. Dzieje się to wtedy, kiedy Bóg dokonuje kenozy, przechodząc do wymiaru tego, co inne niż On sam, co nie-Boskie. Owszem, Bóg mógłby stworzyć świat bez Wcielenia Słowa, lecz z tym twierdzeniem daje się pogodzić także i to, że możliwość stworzenia znajduje swoje uzasadnienie w jeszcze bardziej radykalnej możliwości kenozy Boga. Tym samym, mówi Rahner, dochodzimy do tego, czym w swojej najgłębszej istocie jest człowiek: możliwym Innym, gdy Bóg zechce dokonać kenozy i zrezygnować nie ze swego Boskiego sposobu bycia, nie rezygnując jednak ze swej istoty, jest człowiek jako możliwy brat Jezusa Chrystusa. Ze swej natury człowiek to potentia oboedientialis dla unii hipostatycznej i dla łaski Jezusa Chrystusa ${ }^{11}$.

W oparciu o unię hipostatyczną Rahner formułuje jedno ze swoich najbardziej znanych twierdzeń, określających formalnie związek chrystologii i antropologii ${ }^{12}$, zaś w istocie rzeczy mówiący o zjednoczeniu człowieka z Bogiem: „W odwołaniu do Boga i do człowieka chrystologia jawi się jako najbardziej radykalne, przewyższające wszystko powtórzenie teologicznej antropologii”'13. Choć teologiczna antropologia nie może mieć innego kryterium i innej miary niż chrystologia, to jednak nie można - w przekonaniu Rahnera - szkicować teologicznej antropologii jednokierunkowo, wychodząc jedynie od chrystologii. Choć wydaje się to paradoksalne, to jednak oznaczałoby to jakieś ograniczenie dla antropologii, gdyby jej projektu dokonywać wychodząc wyłącznie od jej

11 Por. K. Rahner, Potentia oboedientialis, w: Sacramentum Mundi, Bd. III, Hg. K. Rahner, A. Darlap, Freiburg/Br. 1969, kol. 1245-1249.

12 Relacja chrystologii i antropologii zajmowała wielu teologów. Wystarczy tu wskazać choćby na Karla Bartha (por. E. H. Friedmann, Christologie und Anthropologie. Methode und Bedeutung der Lehre vom Menschen in der Theologie Karl Barths, Münstwerschwarzach 1972) czy Waltera Kaspera (por. Z. Joha, Christologie und Anthropologie. Eine Verhältnisbestimmung unter besonderer Berücksichtigung des theologischen Denkens Walter Kaspers, Freiburg - Basel - Wien 1992).

13 K. Rahner, Anthropologie (Theologische), kol. 626. 
ostatecznego celu: wcześniejsze doświadczenie nie znosi bowiem i nie wyklucza wcześniejszego. W taki sposób Rahner domaga się dowartościowania realnej historii.

\section{Karl Rahner - nadal aktualny?}

Powyższe myśli, zaczerpnięte z przebogatego dorobku Karla Rahnera, doczekały się zarówno głębokich analiz jak i miażdżącej krytyki. Zarzucano mu właściwie wszystko: wspieranie modernizmu, protestantyzację katolickiej teologii, nieuzasadniony optymizm, oparty na pominięciu krzyża z jednoczesnym podkreśleniem podnoszącej wszystko do poziomu Bożego istnienia łaski. Co ma nam do powiedzenia dziś, w naszej aktualnej sytuacji, Karl Rahner? Co przetrwało $z$ jego dorobku - i co przetrwa, w aspekcie antropologii teologicznej choćby?

Ktoś, kto zetknąl się z teologiczną myślą Karla Rahnera jedynie naskórkowo, może ulec dość powszechnemu przekonaniu, że twórca metody transcendentalnej ${ }^{14} \mathrm{w}$ teologii, wychodząc od człowieka, włącza się w nurt myśli humanistycznej, łatwo zapominającej o Bogu. W rzeczywistości jest zupełnie przeciwnie. Rahner zaczyna od człowieka i jego doświadczenia, a nawet przed-doświadczenia, ale po to, by ponad wszelką wątpliwość wykazać, że człowiek bez Boga nie istnieje, co więcej, jest nie do pomyślenia. Wyrażone skomplikowanym językiem filozoficznej analizy Summy teologicznej św. Tomasza z Akwinu, czytanego i interpretowanego przez pryzmat tomizmu transcendentalnego Josepha Maréchala oraz egzystencjalnej filozofii Martina Heideggera, przekonanie jest jedno: każdym aktem swojego istnienia, chęci i myślenia człowiek potwierdza istnienie Boga, od którego pochodzi i ku któremu zmierza ${ }^{15}$. Użycie języka filozoficznego, nawet jeśli jest on związany z konkretną epoką i kulturą, zwłaszcza myślową, było głęboko przemyślane i celowe. Rahner nie zamierzał bowiem ograniczać się jedynie do ściśle określonej grupy wyznaniowej, do ludzi już przekonanych, ale myślał o wiele szerzej - o wszystkich ludziach nierezygnujących z użycia własnego rozumu, ze zdolności i radości myślenia. Tym, co Karl Rahner przekazuje naszym czasom, filozofom i teologom borykającym się z ponowoczesnym rozwodnieniem tak filozofii jak i teologii ${ }^{16}$, jest zadanie tak pilne, jak odpowiedzialne i trudne: wyrazić w języku naszej epoki podstawową prawdę o zasadności bycia chrześcijaninem, o pięknie człowieczeństwa opartego na Bogu, a zarazem o bezsensie i tragedii ateizmu. Podwaliny swojej teologii

$14 \quad$ Por. N. Knoepffler, Der Begriff „transzendental” bei Karl Rahner. Zur Frage seiner Kantischen Herkunft, Innsbruck - Wien 1993.

15 Por. K. Rahner, Geist in Welt.

16 Por. I. Bokwa, Teologia w warunkach nowoczesności i ponowoczesności, Sandomierz 2010. 
Rahner tworzył w dobie wojującego ateizmu, który tak na płaszczyźnie teorii jak i praktyki wszelkimi możliwymi sposobami starał się wykazać, że Bóg to chimera, wytwór chorej ludzkiej wyobraźni, co więcej - wyrafinowany wróg człowieka. Całość teologicznej myśli i działalności Karla Rahnera służyła wykazaniu błędności i szkodliwości takiego myślenia i takiej postawy życiowej. Zarówno człowiek jak i jego refleksja o otaczającym go świecie są możliwe, gdyż istnieje miłujący Bóg, pragnący udzielić się na zewnątrz, stać się darem dla swojego stworzenia ${ }^{17}$. Warto wczytać się w Rahnerowską teorię symbolu urzeczywistniającego, opracowaną na bazie chrystologii ${ }^{18}$. Człowieczeństwo Jezusa Chrystusa nie jest przypadkową „liberią”, przyodziewaną przez niewidzialne Słowo, Boży Logos, lecz rzeczywistością ontycznie tworzoną przez Boga jako Jego wyraz na zewnątrz. Dopiero wtedy sensownie można powiedzieć, że człowiek jest pytaniem, a Jezus Chrystus odpowiedzią ${ }^{19}$.

Tym, co uderza podczas lektury dzieł Karla Rahnera, również w tłumaczeniu na języki obce, jest potęga jego teologii jako teologii systematycznej. To fakt, jego teologia to nie żadna łatwa fabuła, narracja, ale kawał porządnej roboty systematyka. Dzięki temu jego myśl pozostaje czytelna i komunikatywna. Obojętnie na jaki temat pisał ten wielki teolog, przyświecała mu tylko jedna myśl: pokazać człowieka w jego niezwykłej godności umiłowanego i chcianego dziecka Bożego. Teologia Rahnera jest przemożnie teo-centryczna i chrysto- centryczna. Uwzględniając takie założenie interpretacyjne, można przystępować do lektury i interpretacji jego teologii, również wtedy, gdy się ją czyta w kluczu tak zwanych teologii dopełniaczowych (np. teologia czy chrystologia transcendentalna).

Dzieło Karla Rahnera jest jednoznacznie teologią:

17 Opierając się na artykule Theologie und Anthropologie, zamieszczonym przez K. Rahnera w VIII tomie jego Schriften zur Theologie, Einsiedeln 1967, s. 43-65, K. Góźdź formułuje trzy zasadnicze aksjomaty korelacji teologii i antropologii: „Antropologia teologiczna pyta w sposób aprioryczno-transcendentalny o istotę człowieka, o jego transcendentalną strukturę bytu oraz o strukturę doświadczenia, które zakłada i warunkuje jego historyczny byt. - Antropologia teologiczna ma swój punkt wyjścia w pierwotnej wypowiedzi teologicznej. Jest to refleksja nad człowiekiem, która bazuje na Objawieniu Bożym w Jezusie Chrystusie. Chodzi o to, żeby nie stwarzać zależności od antropologii świeckiej. - Antropologia teologiczna w swoim ukierunkowaniu antropocentrycznym nie jest żadnym przeciwieństwem teologicznej teocentryki. Antropocentryka i teocentryka teologii tworzą dwie perspektywy jednej i tej samej rzeczywistości, które wzajemnie się warunkują i uzupełniają" (K. Góźdź, Teologia człowieka, s. 229). Por. także: J. B. Metz, Antropocentrismo cristiano. Studio sulla mentalità di Tommaso d'Aquino, Torino 1969.

18 Por. K. Rahner, Zur Theologie des Symbols, w: K. Rahner, Schriften zur Theologie, Bd. IV, Einsiedeln 1959, s. 275-311.

19 Por. I. Bokwa, Wprowadzenie do teologii Karla Rahnera, Tarnów 1996, s. 108-112: „Człowiek jako pytanie". 
Podstawowym źródłem teologicznej interpretacji sensu świata, człowieka i historii jest Bóg. Jest On rozumiany jako niestworzona łaska Jego samoudzielania się (i to jest święta tajemnica), w którym to samoudzieleniu staje się On nam bliski i stanowi centrum naszej egzystencji. Jako łaska Chrystusa kulminuje to pełne łaski historiozbawcze samoobjawienie się trynitarnego Boga w historycznej postaci Jezusa z Nazaretu, który jest eschatologicznym apogeum samoobjawienia się Boga i Jego nieodwracalnym ukazaniem się wewnątrz historii ludzkości ${ }^{20}$.

Słowa klucze: antropologia teologiczna, Karl Rahner, teologia transcendentalna, relacja chrystologii i antropologii, ateizm.

\section{Bibliografia:}

1. Bokwa I., Christologie als Anfang und Ende der Anthropologie. Über das gegenseitige Verhältnis zwischen Christologie und Anthropologie bei Karl Rahner, Frankfurt am Main - Bern - New York - Paris 1990.

2. Bokwa I., Teologia w warunkach nowoczesności i ponowoczesności, Sandomierz 2010.

3. Bokwa I., Wprowadzenie do teologii Karla Rahnera, Tarnów 1996.

4. Friedmann E. H., Christologie und Anthropologie. Methode und Bedeutung der Lehre vom Menschen in der Theologie Karl Barths, Vier-Türme-Verlag, Münstwerschwarzach 1972.

5. Góźdź K., Teologia człowieka. Z najnowszej antropologii niemieckiej, Lublin 2006.

6. Granat W., Antropologia - teologiczna, C: Antropologia systematyczna, w: Encyklopedia Katolicka, t. I, red. F. Gryglewicz, R. Łukaszyk, Z. Sułowski, Lublin 1973, kol. 698-702.

7. Joha Z., Christologie und Anthropologie. Eine Verhältnisbestimmung unter besonderer Berücksichtigung des theologischen Denkens Walter Kaspers, Freiburg - Basel - Wien 1992.

8. Knoepffler N., Der Begriff „transzendental” bei Karl Rahner. Zur Frage seiner Kantischen Herkunft, Innsbruck - Wien 1993.

9. Metz J. B., Antropocentrismo cristiano. Studio sulla mentalità di Tommaso d'Aquino, Torino 1969.

10. Rahner K., Antropologie (Theologische), w: Lexikon für Theologie und Kirche, Bd. I, J. Höfer, K. Rahner (Hg.), 2. Aufl., Freiburg/Br. 1986, kol. 623.

11. Rahner K., Geist in Welt. Zur Metaphysik der endlichen Erkenntnis bei Thomas von Aquin, Innsbruck 1939.

12. Rahner K., Hörer des Wortes. Zur Grundlegung einer Religionsphilosophie, München 1941.

13. Rahner K., Potentia oboedientialis, w: Sacramentum Mundi, Bd. III, Hg. K. Rahner, A. Darlap, Freiburg/Br. 1969, kol. 1245-1249.

14. Rahner K.,Theologie und Anthropologie, w: K. Rahner, Schriften zur Theologie, Bd. VIII, Einsiedeln 1967.

$20 \quad$ K. Góźdź, Teologia czlowieka..., s. 253-254. 
15. Rahner K., Zur Theologie des Symbols, w: K. Rahner, Schriften zur Theologie, Bd. IV, Einsiedeln 1959.

16. Verweyen H., Wie wird ein Existential übernatürlich? Zu einem Grundproblem der Anthropologie Rahner K.s, „Trierer Theologische Zeitschrift” 95(1986) z. 2. 